\title{
NAMA PANGGILAN ATAU SAPAAN BERDASARKAN ANGGOTA KELUARGA YANG MENINGGAL DALAM BAHASA KENYAH LEPOQ JALAN DI DESA LUNG ANAI
}

\section{NICKNAMES BASED ON FAMILY MEMBERS WHO DIED IN THE LANGUAGE OF KENYAH LEPOQ JALAN IN LUNG ANAI VILLAGE}

\author{
Nurul Masfufah \\ Kantor Bahasa Kalimantan Timur \\ Jalan Batu Cermin 25 Sempaja Utara, Samarinda \\ Posel: mashfufahnurul@yahoo.com
}

*) Naskah diterima: 25 September 2019; direvisi: 15 November 2019; disetujui: 3 Desember 2019

\begin{abstract}
Abstrak
Penelitian mengenai nama panggilan atau sapaan berdasarkan anggota keluarga yang meninggal dalam bahasa Kenyah Lepoq Jalan ini penting dilakukan sebagai bentuk pendokumentasian dan pelestarian budaya. Penelitian ini bertujuan untuk mendeskripsikan bentuk dan fungsi nama panggilan atau sapaan berdasarkan anggota keluarga yang meninggal. Teknik pengumpulan data diperoleh dari informan melalui wawancara dengan teknik rekam dan catat. Teknik analisis data dalam penelitian ini menggunakan analisis deskriptif, yaitu dengan analisis data linguistik dan sosiolinguistik. Adapun model analisis data yang digunakan, yaitu analisis model interaktif yang terdiri atas tiga komponen analisis, yaitu reduksi data, sajian data, dan penarikan simpulan. Berdasarkan hasil penelitian dan pembahasan, diperoleh bentuk nama panggilan atau sapaan berdasarkan kematian anggota keluarga dalam bahasa Kenyah Lepoq Jalan diklasifikasikan menjadi tiga, yaitu nama panggilan yang bersifat netral (perempuan dan laki-laki), nama panggilan untuk jenis kelamin perempuan, dan nama panggilan untuk jenis kelamin laki-laki. Adapun fungsi dari pemakaian sapaan tersebut, yaitu (a) sebagai identitas dari masyarakat Kenyah Lepoq Jalan, (b) sebagai penanda status mitra tutur, (c) penanda jenis kelamin mitra tutur, (d) sebagai interaksi sosial, dan (e) sebagai kontrol sosial.
\end{abstract}

Kata kunci: nama panggilan, keluarga yang meninggal, bahasa Kenyah Lepoq Jalan

\begin{abstract}
Research on nicknames based on family members who died in Kenyah Lepoq Jalan language is essential as a form of documentation and cultural preservation. This study aims to describe the form and function of nicknames based on family members who died. Data collection techniques were obtained from informants through recording interviews and note-taking. It is descriptive using the analysis of linguistic and sociolinguistics data. The data analysis model used is an interactive model consisting of three components of analysis, namely data reduction, data display, and conclusions drawing. Based on the results of research and discussion, the forms of nicknames based on the family members who died in Kenyah Lepoq Jalan are classified into three, namely neutral nicknames (women and men), nicknames for women, and nicknames for men. Those nicknames are used (a) as the identity, (b) as the marker of the hearer status, (c) as the marker of the hearer gender, (d) as a social interaction, and (e) as a social control in the community of Kenyah Lepoq Jalan.
\end{abstract}

Keywords: nickname, family who died, Kenyah Lepoq Jalan language 


\section{PENDAHULUAN}

Di tengah perubahan zaman yang begitu cepat dengan segala implikasinya, identitas suatu bangsa ataupun etnis akan dengan mudah tergerus. Kondisi ini diperparah dengan acuh tak acuhnya generasi muda terhadap budaya daerah dan bahasanya. Padahal, bahasa daerah merupakan pemerkaya bahasa Indonesia. Keberadaan bahasa daerah juga merupakan bukti keragaman budaya.

Setiap budaya mempunyai suatu keunikan yang dijadikan sebagai identitas sosial untuk menyatakan tentang siapa mereka dan mengapa mereka ada. Indonesia terdiri atas berbagai suku atau etnik yang memiliki keunikan budaya masing-masing, termasuk segi bahasanya. Budaya yang sudah melekat pada setiap suku tersebut menjadi ciri khas yang membedakan antara budaya yang satu dengan yang lainnya. Dengan kata lain, kebudayaan dapat mewakili suatu perilaku personal ataupun kelompok (Liliweri, 2013:119).

Penggunaan bentuk nama panggilan atau sapaan yang berbeda-beda di antara suku-suku di Indonesia merupakan salah satu budaya yang perlu dilestarikan dan didokumentasikan. Misalnya, masyarakat Bali menggunakan nama, seperti Made dan Wayan untuk nama anak disesuaikan dengan urutan nomor kelahiran dan disesuaikan dengan kasta untuk menunjukkan status sosialnya. Adapun suku Batak menggunakan nama marga untuk memberikan nama pada anaknya, sedangkan suku Sunda biasanya disesuaikan dengan peristiwa yang menyertai hari kelahiran, meniru nama tokoh, kata sifat, dan bentuk nama penyapa atau panggilan dalam bahasa Sunda (Rahayu, 2000:13).

Pada dasarnya nama panggilan atau sapaan merupakan unsur bahasa yang paling penting dalam melakukan komunikasi karena kata sapaan sangat berguna untuk memulai percakapan dalam suatu kegiatan komunikasi, baik itu dengan teman, keluarga, dan lain sebagainya. Pada komunikasi yang terjadi di masyarakat, tuturan biasanya dibangun oleh penggunaan kata sapaan yang tepat. Hal itu sejalan dengan fungsi penggunaan kata sapaan, yakni untuk menegur, menyapa bahkan memulai suatu pembicaraan dengan mitra tutur. Dengan adanya penggunaan kata sapaan dalam bertutur, dapat diketahui kepada siapa tuturan atau sapaan tersebut ditujukan. Oleh karena itu, kata sapaan memiliki makna sosial yang penting.

Istilah kata sapaan adalah suatu ujaran yang dipergunakan seseorang untuk menegur, menyapa atau memanggil seseorang secara adat sebagai lawan bicara. Dalam bahasa Indonesia, kata sapaan yang digunakan pembicara untuk menyapa lawan bicaranya cukup bervariasi, misalnya jenis kata sapaan yang paling banyak digunakan adalah istilah kekerabatan dan nonkekerabatan (Saadah, dkk, 2016:1).

Dalam masyarakat Dayak Kenyah, termasuk dialek Lepoq Jalan memiliki keunikan atau ciri khas dalam pemberian nama panggilan atau sapaan, yaitu memberikan nama panggilan kepada mereka yang berduka atau anggota keluarganya yang meninggal dunia. Misalnya, dalam masyarakat Kenyah dialek Lepoq Jalan jika ada pasangan suami istri atau orang tua yang anaknya sudah meninggal semua, nama piat tubang disandingkan pada nama kedua orang tuanya. Apabila yang meninggal dunia itu anaknya yang kedua, nama panggilan atau sapaan buyoq menjadi nama penggilan atau nama tambahan untuk ibu anak yang meninggal tersebut, sedangkan nama panggilan atau sapaan untuk bapaknya menggunakan kata empui di depan nama aslinya.

Masyarakat Kenyah Lepoq Jalan di Desa Lung Anai, Loa Kulu, Kutai Kartanegara masih mengenal dan menggunakan nama 
panggilan atau sapaan dalam bertutur sapa, baik dalam kekerabatan maupun di luar kekerabatan. Kata sapaan ini masih sangat aktif digunakan dalam tindak tutur seharihari, baik dilakukan oleh generasi muda ataupun tua. Masyarakat Kenyah Lepoq Jalan di Lung Anai masih cenderung menggunakan kata sapaan yang bentuknya dapat dimengerti oleh generasi satu dengan generasi lainnya. Dengan munculnya kekhasan dan keunikan dari bahasa Kenyah Lepoq Jalan di Desa Lung Anai, Loa Kulu, Kutai Kartanegara inilah menarik untuk dikaji lebih mendalam melalui kajian nama panggilan atau sapaan berdasarkan kematian anggota keluarganya.

Berdasarkan latar belakang masalah di atas, masalah yang akan dibahas dalam kajian ini, yaitu bagaimana bentuk dan fungsi nama panggilan atau sapaan berdasarkan kematian anggota keluarga dalam bahasa Kenyah Lepoq Jalan di Desa Lung Anai, Kecamatan Loa Kulu, Kabupaten Kutai Kartanegara. Adapun tujuan penelitian atau kajian ini, yaitu untuk mendeskripsikan bentuk dan fungsi nama panggilan atau sapaan berdasarkan kematian anggota keluarga dalam bahasa Kenyah Lepoq Jalan di Desa Lung Anai, Kecamatan Loa Kulu, Kabupaten Kutai Kartanegara.

\section{LANDASAN TEORI}

Kridalaksana dalam (Martina dan Irmayani, 2004:6) menyatakan bahwa satuan bahasa mempunyai sistem tutur sapa, yakni sistem yang mempertautkan seperangkat kata atau ungkapan yang dapat digunakan untuk menyebut dan memanggil para pelaku dalam suatu peristiwa bahasa. Oleh sebab itu, sapaan merupakan salah satu cara penyampaian maksud dari yang menyapa kepada yang disapa, baik secara lisan maupun tulis. Dalam proses pertuturan tersebut melibatkan penutur, lawan tutur, dan pesan atau objek yang dituturkan, tetapi dengan syarat mitra tutur dalam keadaan sadar atau menyadari adanya tuturan dari penutur (Chaer, 2010:39). Crystal (dalam Syafyahya, dkk. 2000:3) menyatakan bahwa sapaan merupakan cara mengacu seseorang di dalam interaksi linguistik yang dilakukan secara langsung. Sementara itu, Pusat Bahasa (2014:1225) menyatakan bahwa sapaan adalah kata atau frasa untuk saling merujuk dalam pembicaraan dan yang berbeda-beda menurut sifat hubungan di antara pembicara itu, seperti Anda, Ibu, Saudara. Dengan demikian, kata sapaan adalah katakata yang dapat digunakan untuk menyapa, menegur, menyebut orang kedua, atau orang yang hendak diajak komunikasi, baik secara lisan maupun tertulis.

Nama panggilan adalah nama yang digunakan dalam penyapaan (Pusat Bahasa, 2014: 950). Dalam kajian ini nama panggilan sama dengan kata sapaan. Kata sapaan menurut Brown dan Gilman merujuk pada kata ganti yang digunakan untuk menyapa orang kedua (Fasold, 1994: 3). Adapun menurut Kridalaksana (1984:14), kata sapaan merujuk pada kata atau ungkapan yang dipakai untuk menyebut dan memanggil para pelaku dalam suatu peristiwa bahasa. Pelaku yang dimaksud merujuk pada pembicara, lawan bicara, serta orang yang sedang dibicarakan. Berdasarkan pemaparan tersebut, dapat diketahui bahwa terdapat dua unsur penting dalam sistem tutur sapa, yaitu kata atau ungkapan dan para pelaku dalam suatu peristiwa bahasa. Kata atau ungkapan yang digunakan dalam sistem tutur sapa merujuk pada kata sapaan atau panggilan. Para pelaku dalam suatu peristiwa bahasa merujuk pada pembicara dan lawan bicara. Kata sapaan atau panggilan berfungsi untuk memperjelas kepada siapa pembicaraan itu ditujukan.

Nama panggilan atau sapaan tersebut memiliki peranan penting karena sistem penyapa yang berlaku dalam bahasa ter- 
tentu akan berbeda dengan sistem penyapa yang berlaku dalam bahasa lain, seperti bahasa tulis. Letak perbedaan itu tidak hanya terletak pada kosakata sapaan saja, tetapi pada sikap penuturnya ketika proses penggunaan sapaan berlangsung. Seiring dengan ungkapan itu, Kridalaksana (dalam Martina dan Irmayani, 2004:6) mengungkapkan bahwa, kata sapaan dapat diartikan sebagai morfem, kata atau frasa yang digunakan untuk saling merujuk dalam situasi pembicaraan yang berbeda-beda dan berkaitan dengan sifat hubungan antara pembicara. Oleh karena itu, adanya penggunaan kata sapaan tersebut, dapat diketahui kepada siapa tuturan ditujukan.

Pateda (1987:69) mengungkapkan bahwa dengan adanya bentuk atau kata sapaan, dapat memengaruhi kata yang dipergunakan dan cara pengungkapannya. Hal ini disebabkan karena adanya masyarakat kita yang memperhatikan hubungan sosial antarmanusia. Tata krama dalam kehidupan masyarakat yang menuntut akan adanya pertuturan yang sesuai dengan martabat dan posisinya berkenaan dengan umur, status sosial, dan keakraban. Dari uraian di atas, dapat disimpulkan bahwa kata sapaan merupakan seperangkat kata, morfem, frasa atau ungkapan yang digunakan untuk menyapa atau memulai pembicaraan dengan lawan bicara dalam suatu peristiwa bahasa.

\section{METODE}

Penelitian ini merupakan penelitian kualitatif dengan metode deskriptif. Moleong (2005:6) menjelaskan bahwa penelitian kualitatif adalah penelitian yang menghasilkan prosedur analisis yang tidak menggunakan prosedur analisis statistik atau cara kuantitatif lainnya. Metode ini menyarankan bahwa penelitian yang dilakukan, sematamata hanya berdasarkan pada fakta yang ada atau fenomena yang memang secara nyata ada pada penuturnya. Dengan metode deskriptif ini dapat mendeskripsikan bentuk nama panggilan atau sapaan berdasarkan kematian anggota keluarga dalam bahasa Kenyah dialek Uma Lung.

Sementara itu, metode yang digunakan untuk pengumpulan data, yaitu metode wawancara dengan teknik rekam dan catat. Adapun wawancara dilakukan dengan percakapan antara peneliti dan informan (penutur jati bahasa Kenyah Lepoq Jalan), yaitu Bapak Pelujuk (69 tahun), Ibu Lewi (48 tahun), dan Bapak Gun Lahang (50 tahun). Wawancara ini dilakukan untuk mengetahui berbagai informasi dan data, terutama namanama panggilan atau sapaan yang berkenaan dengan kematian anggota keluarga. Dalam hal ini peneliti menggunakan teknik wawancara tidak terstruktur atau terbuka, yaitu wawancara bebas, di mana pewawancara tidak menggunakan pedoman wawancara yang telah tersusun secara sistematis dan lengkap untuk pengumpulan data (Widoyoko, 2013:44).

Metode analisis data yang digunakan, yaitu metode deskriptif dengan teknik deskriptif analitik dengan model interaktif, seperti yang dikemukakan oleh Miles dan Huberman (2007:19-20), yang terdiri atas tiga komponen analisis, yaitu reduksi data, sajian data, dan penarikan simpulan. Adapun langkah-langkah yang dilakukan dalam menganalisis data, antara lain mengatur atau mengurutkan data yang sudah dikumpulkan, mengklasifikasikan data berdasarkan kategori atau kriterianya, dan melakukan analisis data, serta mendeskripsikan dan menyimpulkannya secara singkat dan jelas.

\section{PEMBAHASAN}

Masyarakat Dayak Kenyah Lepoq Jalan di desa Lung Anai, Kecamatan Loa Kulu, Kabupaten Kutai Kartanegara memiliki suatu kebiasaan untuk memberikan nama panggilan atau sapaan pada mereka yang 
berduka. Tradisi ini merupakan kebiasaan lama yang sudah turun-temurun dari etnis Kenyah. Sebelum menjelaskan mengenai bentuk dan fungsi nama panggilan atau sapaan tersebut, berikut ini akan dijelaskan secara singkat proses upacara kematian suku Dayak Kenyah.

Masyarakat Dayak Kenyah jika ada anggota keluarganya yang meninggal dunia setelah jenazahnya dimandikan kemudian dikenakan pakaian lengkap, akan dimasukkan ke dalam peti mati. Di dalam peti mati tersebut dimasukkan sebatang tebu dan air tebu yang ditaruh dalam sepotong bambu yang ditutup rapat. Hal ini dimaksudkan untuk memberi perbekalan kepada roh yang akan mengembara jauh (Bappeda, 2012:402).

Upacara selanjutnya, yaitu mengantar roh tersebut ke suatu tempat penampungan sementara atau pesanggrahan sebelum dibawa ke tempat peristirahatan terakhir untuk roh orang yang meninggal secara wajar dan tempat tertentu untuk orang yang meninggal secara tidak wajar. Proses pengantaran tersebut dipimpin oleh seorang petugas adat dengan diiringi lagu bernada ratapan yang menceritakan bagaimana proses roh tersebut melakukan perjalanan menuju tempat tersebut. Setelah selesai upacara tesebut, jenazah siap diantar ke tempat pemakaman dan dimakamkan di atas makam yang dipancang nisan yang terbuat dari kayu. Saat ini sebagian besar diberi salib untuk yang menganut agama Protestan dan Katolik. Zaman dahulu apabila meninggal secara tidak wajar diberi bendera merah, sedangkan yang meninggal secara wajar diberi bendera putih, kuning, hijau, dan diberi kembang-kembang (Bappeda, 2012:403).

Setelah pulang dari acara penguburan, para pengantar jenazah sebelum kembali ke rumah masing-masing harus mencuci kaki dengan air yang disimpan di dalam labu air, setalah itu mandi ke sungai. Hal ini juga dilakukan oleh beberapa suku lain, seperti Benuaq dan Tonyooi untuk membersihkan diri agar kehidupan mendatang lebih baik dari sebelumnya dan terhindar dari segala penyakit yang dapat menyebabkan kemalangan.

Dalam suku Kenyah, setelah selesai membersihkan diri, biasanya keluarga terdekat dari yang meninggal dunia tersebut mengenakan pakaian kabung selama tujuh hari berturut-turut. Pakaian tersebut terbuat dari kulit kayu talon yang dipasang di kepala berbentuk kerudung kerucut. Pada hari kedelapan dilakukan upacara memberikan persembahan bagi dewa amen sebagai tanda bahwa telah berakhirnya masa berkabung. Adat kematian yang dilakukan menurut adat lama semuanya dianggap selesai setelah melakukan upacara membersihkan dan memagar kuburan yang umumnya dilakukan setelah selesai masa panen (Bappeda, 2012:403-404).

Dalam suku Kenyah, selama prosesi kematian tersebut belum selesai dilaksanakan, pihak keluarga dekat biasanya sudah menggunakan nama pangilan berkabung yang diletakkan di depan nama yang bersangkutan. Kata panggilan berkabung tersebut berbeda-beda menurut jenis hubungan keluarga yang bersangkutan.

Masyarakat Dayak Kenyah Lepoq Jalan tersebut masih memegang tradisi untuk memberikan nama panggilan atau sapaan pada mereka yang berduka, misalnya jika ada anak keempatnya meninggal dunia, nama sawang disandingkan atau ditambahkan pada nama kedua orang tuanya. Misalnya: anak keempat dari Lewi dan Lahang meninggal dunia, masyarakat Kenyah Lepoq Jalan akan memanggil keduanya dengan nama panggilan atau sapaan Sawang Lahang dan Sawang Lewi. Apabila yang meninggal dunia itu bapaknya, anak perempuannya akan mendapat nama tambahan panggilan utan di depan namanya dan nama 
tambahan panggilan untuk anak laki-lakinya itu adalah uyau. Misalnya, bapak dari Marta dan Luhat meninggal dunia, kedua anak tersebut dipanggil dengan nama tambahan di depan namanya, yaitu Utan Marta (perempuan) dan Uyau Luhat (lakilaki). Dengan demikian, nama tambahan panggilan itu melekat atau berada di depan nama aslinya. Nama tambahan panggilan berdasarkan kematian anggota keluarganya ini hanya dipakai untuk sapaan saja, tidak dituliskan dalam identitas namanya. Nama panggilan atau sapaan ini digunakan dalam komunikasi sehari-hari oleh masyarakat Kenyah Lepoq Jalan. Berikut ini klasifikasi nama panggilan atau sapaan duka berdasarkan jenis kelamin yang disapa.

\section{Nama Panggilan atau Sapaan untuk Semua Jenis Kelamin (Netral)}

Nama panggilan atau sapaan yang disandingkan di depan nama seseorang, baik laki-laki maupun perempuan (netral) ada sembilan bentuk, yaitu ilun, upu, bayei, encak, sawang, piat tubing, pe'at, ja'at, dan nyawa. Hal ini lebih banyak dibandingkan dengan nama panggilan untuk laki-laki saja ataupun perempuan saja. Berikut secara singkat gambaran nama panggilan atau sapaan untuk semua jenis kelamin dalam bentuk tabel.

Tabel 1. Nama Panggilan atau Sapaan untuk Semua Jenis Kelamin (Netral)

\begin{tabular}{|c|l|l|}
\hline No. & Kata Penyapa & \multicolumn{1}{c|}{ Referen } \\
\hline 1. & Ilun & $\begin{array}{l}\text { laki-laki ataupun perempuan yang ibunya } \\
\text { meninggal dunia. }\end{array}$ \\
\hline 2. & Upu & $\begin{array}{l}\text { laki-laki ataupun perempuan yang nenek atau } \\
\text { kakeknya meninggal dunia. }\end{array}$ \\
\hline 3. & Bayei & $\begin{array}{l}\text { laki-laki ataupun perempuan yang kakaknya } \\
\text { meninggal dunia. }\end{array}$ \\
\hline 4. & Encak & $\begin{array}{l}\text { laki-laki ataupun perempuan yang anak } \\
\text { ketiganya meninggal dunia. }\end{array}$ \\
\hline 5. & Sawang & $\begin{array}{l}\text { laki-laki ataupun perempuan yang anak } \\
\text { keempatnya meninggal dunia. }\end{array}$ \\
\hline 6. & Piat tubang & $\begin{array}{l}\text { laki-laki ataupun perempuan yang anaknya } \\
\text { meninggal semua. }\end{array}$ \\
\hline 7. & Pe'at & $\begin{array}{l}\text { laki-laki ataupun perempuan yang cucunya } \\
\text { meninggal dunia. }\end{array}$ \\
\hline 8. & Ja'at & $\begin{array}{l}\text { laki-laki ataupun perempuan yang saudaranya } \\
\text { meninggal semua. }\end{array}$ \\
\hline 9. & Nyawa & $\begin{array}{l}\text { laki-laki ataupun perempuan yang memiliki } \\
\text { anak beranjak dewasa sebagai harapannya } \\
\text { meninggal dunia. Selain itu, juga dipakai untuk } \\
\text { laki-laki ataupun perempuan yang memiliki } \\
\text { anak yang baru lahir meninggal dunia padahal } \\
\text { diharapkan sekali kehadirannya. }\end{array}$ \\
\hline
\end{tabular}


Berdasarkan data tersebut, dapat dijelaskan secara singkat bahwa nama tambahan panggilan atau sapaan ilun, upu, bayei, encak, sawang, piat tubing, pe'at, ja'at, dan nyawa pemakaiannya bersifat netral, yaitu dapat digunakan untuk nama panggilan atau sapaan, baik laki-laki maupun perempuan Dayak Kenyah Lepoq Jalan berdasarkan anggota keluarganya yang meninggal dunia. Berikut ini pemaparan masingmasing nama panggilan atau sapaan tersebut.

(1) Nama panggilan ilun, yaitu nama panggilan atau sapaan untuk seseorang, baik laki-laki maupun perempuan apabila ibunya meninggal dunia. Misalnya, Gun (laki-laki) dan Marta (perempuan) sudah tidak mempunyai ibu lagi atau ibunya sudah meninggal, kedua orang itu akan dipanggil Ilun Gun, dan Ilun Marta. Jadi, kata Ilun disematkan atau disandingkan di depan nama mereka.

(2) Nama panggilan Upu, yaitu nama panggilan atau sapaan untuk seseorang, baik laki-laki maupun perempuan apabila nenek atau kakeknya meninggal dunia, Misalnya, nenek atau kakek dari Bid (laki-laki) dan Norti (perempuan) meninggal dunia, cucu yang bernama Bid dan Norti tersebut akan dipanggil Upu Bid dan Upu Norti. Jadi, kata Upu akan disandingkan di depan nama mereka.

(3) Nama panggilan Bayei, yaitu nama panggilan atau sapaan untuk seseorang, baik laki-laki maupun perempuan apabila kakaknya meninggal dunia. Misalnya, Tingai (laki-laki) dan Bilung (perempuan) mempunyai kakak (laki-laki atau perempuan) yang sudah meninggal dunia, kedua orang itu akan dipanggil Bayei Tingai dan Bayei Bilung. Jadi, nama tambahan Bayei tersebut disandingkan di depan nama mereka.
(4) Nama panggilan Encak, nama panggilan atau sapaan untuk seseorang, baik lakilaki maupun perempuan yang anak ketiganya meninggal dunia. Misalnya, Anak ketiga dari pasangan suami istri yang bernama Lewi (perempuan) dan Idam (laki-laki) meninggal dunia, kedua orang tuanya tersebut mendapat nama tambahan sebagai nama panggilan, yaitu sapaan Encak di depan nama mereka. Dengan demikian, kedua orang tua tersebut akan dipanggil Encak Lewi dan Encak Idam

(5) Nama panggilan Sawang, nama panggilan atau sapaan untuk seseorang, baik laki-laki maupun perempuan apabila anak keempatnya meninggal dunia. Misalnya, Anak keempat dari pasangan suami istri yang bernama Norti (perempuan) dan Rubin (laki-laki) meninggal dunia, pasangan suami istri tersebut mendapat nama tambahan sebagai nama panggilan, yaitu sapaan Sawang di depan nama mereka. Dengan demikian, pasangan suami istri atau kedua orang tua tersebut akan dipanggil Sawang Norti dan Sawang Rubin.

(6) Nama panggilan Piat tubang, yaitu nama panggilan atau sapaan untuk seseorang, baik laki-laki maupun perempuan apabila anaknya meninggal semua. Misalnya, pasangan dari Luhat dan Marta yang memiliki beberapa anak, tetapi sudah meninggal semua, kedua orang tua itu akan diberi nama tambahan Piat Tubang untuk panggilan atau sapaan di depan nama aslinya. Dengan demikian, nama panggilannya Piat Tubang Luhat dan Piat Tubang Marta.

(7) Nama panggilan Pe'at, yaitu nama panggilan atau sapaan untuk seseorang, baik laki-laki maupun perempuan apabila cucunya meninggal dunia. Misalnya, 
cucu dari Martinus dan Yurni sudah meninggal dunia, kedua orang itu akan diberi nama tambahan $P e^{\prime}$ at untuk panggilan atau sapaan di depan nama aslinya sehingga menjadi $P e^{\prime}$ at Martinus dan Pe'at Yurni.

(8) Nama panggilan $J a^{\prime} a t$, yaitu nama panggilan atau sapaan untuk seseorang, baik laki-laki maupun perempuan apabila saudaranya meninggal semua. Misalnya, Tanyit (anak laki-laki) dan Dinis (anak perempuan) yang masing-masing memiliki beberapa saudara, tetapi meninggal dunia semua sehingga tinggal dirinya. Oleh karena itu, Tanyit dan Dinis mendapat nama tambahan $J a^{\prime} a t$ di depan namanya sebagai nama panggilan atau sapaan mereka sehingga menjadi Ja'at Tanyit dan Ja'at Dinis. Ja'at dalam bahasa Kenyah Lepoq Jalan ini artinya 'jahat'. Menurut kepercayaan mereka, pemberian nama tambahan $J a^{\prime}$ at itu dimaksudkan agar roh-roh halus tidak mengambilnya lagi karena dianggapnya jahat.

(9) Nama panggilan Nyawa, yaitu nama panggilan atau sapaan untuk seseorang, baik laki-laki maupun perempuan yang anaknya sudah beranjak dewasa sebagai harapannya meninggal dunia atau dapat juga anaknya yang baru lahir meninggal dunia padahal diharapkan sekali kehadirannya. Misalnya, pasangan suami istri yang bernama Pajan dan Marta mempunyai anak yang sudah mulai dewasa, tetapi meninggal dunia atau bisa juga memiliki anak satu-satunya yang baru lahir, tetapi meninggal dunia padahal anak tersebut diidam-idamkan kelahirannya. Pasangan Pajan dan Marta tersebut mendapat nama tambahan Nyawa di depan nama- nya sebagai nama panggilan atau sapaan sehingga menjadi Nyawa Pajan dan Nyawa Marta.

Nama panggilan atau sapaan tersebut tidak bersifat permanen atau selamanya. Namun, bergantung status terakhir yang disandangnya berdasarkan kematian anggota keluarganya. Misalnya, Gun awalnya dipanggil Upu Gun karena kakeknya meninggal dunia, setahun kemudian dipanggil dengan sapaan Uyau Gun karena bapaknya meninggal dunia. Dengan demikian, nama panggilan atau sapaan tersebut dapat berubah. Nama panggilan atau sapaan dalam masyarakat Dayak Kenyah Lepoq Jalan ini disesuaikan dengan status terakhirnya berdasarkan kematian anggota keluarganya. Dengan adanya bentuk nama panggilan atau sapaan tersebut, masyarakat akan dapat mengetahui statusnya. Hal ini juga menunjukkan kedekatan atau bentuk empati mereka kepada orang sesukunya yang ditinggalkan anggota keluarganya dengan memberikan nama tambahan duka atau berkabung tersebut.

\section{Nama Panggilan atau Sapaan untuk Jenis Kelamin Perempuan}

Sementara itu, nama panggilan atau sapaan yang ditujukan untuk jenis kelamin perempuan berdasarkan kematian anggota keluarganya ada sekitar enam bentuk, yaitu utan, tubing, uyung, buyoq, balu, dan abing. Berikut secara singkat gambaran nama panggilan atau sapaan untuk semua jenis kelamin dalam bentuk tabel. 
Tabel 2. Nama Panggilan atau Sapaan untuk Jenis Kelamin Perempuan

\begin{tabular}{|c|l|l|}
\hline No. & Kata Penyapa & \multicolumn{1}{c|}{ Referen } \\
\hline 1. & Utan & Orang perempuan yang bapaknya meninggal dunia \\
\hline 2. & Tubing & $\begin{array}{l}\text { Orang perempuan yang anaknya meninggal dunia di } \\
\text { tempat lain, misalnya di perantauan }\end{array}$ \\
\hline 3. & Uyung & perempuan yang anak pertamanya meninggal dunia. \\
\hline 4. & Buyoq & perempuan yang anak keduanya meninggal dunia \\
\hline 5. & Balu & perempuan yang suaminya meninggal dunia. \\
\hline 6. & Abing & perempuan yang bapaknya meninggal dunia. \\
\hline
\end{tabular}

Berdasarkan data di atas, dapat dijelaskan secara singkat bahwa nama tambahan panggilan atau sapaan utan, tubing, uyung, buyoq, balu, dan abing pemakaiannya hanya digunakan untuk nama panggilan atau sapaan bagi perempuan Dayak Kenyah Lepoq Jalan berdasarkan kematian anggota keluarganya. Di bawah ini pemaparan setiap nama panggilan atau sapaan tersebut.

(1) Utan, yaitu nama panggilan atau sapaan untuk seseorang berjenis kelamin perempuan yang bapaknya meninggal dunia. Misalnya, bapak dari Lewi (perempuan) meninggal dunia. Selanjutnya, Lewi akan dipanggil Utan Lewi. Dengan kata lain, Lewi mendapat nama tambahan Utan di depan nama aslinya.

(2) Tubing, yaitu nama panggilan atau sapaan untuk seseorang berjenis kelamin perempuan yang anaknya meninggal dunia di tempat lain. Misalnya, seorang ibu yang bernama Dinis mempunyai anak di perantauan dan anaknya itu meninggal di tempat perantauan tersebut, selanjutnya Dinis akan dipanggil. Tubing Dinis. Dengan kata lain, Dinis mendapat nama tambahan Tubing di depan nama aslinya.

(3) Uyung, yaitu nama panggilan atau sapaan untuk seseorang berjenis kelamin perempuan yang anak pertamanya meninggal dunia. Misalnya, anak pertama dari seorang ibu yang bernama
Li meninggal dunia, selanjutnya $L i$ akan dipanggil dengan sapaan Uyung di depan namanya, yaitu menjadi Uyung $\mathrm{Li}$.

(4) Buyoq, yaitu nama panggilan atau sapaan untuk seseorang berjenis kelamin perempuan yang anak keduanya meninggal dunia. Misalnya, anak kedua dari seorang ibu yang bernama Luwing meninggal dunia, selanjutnya Luwing akan dipanggil dengan sapaan Buyoq di depan namanya, yaitu menjadi Buyoq Luwing.

(5) Balu, yaitu nama panggilan atau sapaan untuk seseorang berjenis kelamin perempuan yang suaminya meninggal dunia. Misalnya, seorang suami dari istri yang bernama Marti meninggal dunia, Marti atau istrinya tersebut akan dipanggil Balu Marti. Dengan kata lain, Marti mendapat nama tambahan Balu di depan nama aslinya.

(6) Abing, yaitu nama panggilan atau sapaan untuk seseorang berjenis kelamin perempuan yang bapaknya meninggal dunia. Misalnya, seorang perempuan yang bernama Yurni mempunyai bapak yang sudah meninggal dunia, Yurni mendapat nama tambahan sebagai nama panggilan, yaitu dengan sapaan Abing di depan nama aslinya. Dengan demikian, Yurni akan dipanggil Abing Yurni. 
Nama Panggilan atau Sapaan untuk Jenis Kelamin Laki-Laki

Adapun nama panggilan atau sapaan yang ditujukan untuk jenis kelamin laki-laki berdasarkan kematian anggota keluarganya hanya ada sekitar empat bentuk, yaitu uyau, ampan, belio dan empui. Berikut secara singkat gambaran nama panggilan atau sapaan untuk semua jenis kelamin dalam bentuk tabel.

Tabel 3. Nama Panggilan atau Sapaan untuk Jenis Kelamin Laki-Laki

\begin{tabular}{|c|l|l|}
\hline No. & Kata Penyapa & \multicolumn{1}{c|}{ Referen } \\
\hline 1. & Uyau & Anak laki-laki yang bapaknya sudah meninggal dunia \\
\hline 2. & Ampan & Orang laki-laki yang istrinya sudah meninggal dunia \\
\hline 3. & Belio & $\begin{array}{l}\text { Orang laki-laki yang anaknya meninggal dunia di tempat } \\
\text { lain, misalnya di perantauan }\end{array}$ \\
\hline 4. & Empui & Orang laki-laki yang anak keduanya sudah meninggal dunia \\
\hline
\end{tabular}

Berdasarkan data tersebut, dapat dijelaskan secara singkat bahwa nama tambahan panggilan atau sapaan uyau, ampan, belio dan empui pemakaiannya hanya digunakan untuk nama panggilan atau sapaan bagi laki-laki Dayak Kenyah Lepoq Jalan berdasarkan anggota keluarganya yang meninggal dunia. Berikut ini pemaparan setiap nama panggilan atau sapaan tersebut.

(1) Uyau, yaitu nama panggilan atau sapaan untuk seseorang berjenis kelamin laki-laki apabila bapaknya meninggal dunia. Misalnya, seorang laki-laki yang bernama Bilung mempunyai bapak yang sudah meninggal dunia, Bilung mendapat nama tambahan sebagai nama panggilan, yaitu dengan sapaan Uyau di depan nama aslinya. Dengan demikian, Bilung akan dipanggil Uyau Bilung. Nama panggilan Uyau (laki-laki) ini pasangannya Utan (perempuan).

(2) Ampan, yaitu nama panggilan atau sapaan untuk seseorang berjenis kelamin laki-laki apabila istrinya meninggal dunia atau sudah duda. Misalnya, seorang istri dari suami yang bernama Pajan meninggal dunia, Pajan atau suaminya tersebut akan dipanggil Ampan Pajan. Dengan kata lain, Pajan mendapat nama tambahan Ampan di depan nama aslinya. Nama panggilan Ampan (lakilaki) ini pasangannya Balu (perempuan).

(3) Belio, yaitu nama panggilan atau sapaan untuk seseorang berjenis kelamin lakilaki apabila anaknya meninggal dunia di tempat lain, misalnya di perantauan. Misalnya, seorang bapak yang bernama Idam mempunyai anak di perantauan dan anaknya itu meninggal di tempat perantauan tersebut, selanjutnya Idam akan dipanggil Belio Idam. Dengan kata lain, Idam mendapat nama tambahan Belio di depan nama aslinya. Nama panggilan Belio (laki-laki) ini pasangannya Tubing (perempuan).

(4) Empui, nama panggilan atau sapaan untuk seseorang berjenis kelamin lakilaki apabila anak keduanya meninggal dunia. Misalnya, anak kedua dari seorang bapak yang bernama Tingai meninggal dunia, selanjutnya Tingai akan dipanggil dengan sapaan Empui di depan namanya, yaitu menjadi Empui Tingai. Nama panggilan Empui (lakilaki) ini pasangannya Luwing (perempuan). 


\section{Fungsi Nama Panggilan atau Sapaan dalam Masyarakat Kenyah Lepoq Jalan}

Bahasa Kenyah Lepoq Jalan juga memiliki fungsi-fungsi tertentu dalam pemakaiannya, termasuk bentuk nama panggilan atau sapaan berkabung berdasarkan kematian anggota keluarganya. Bentuk nama panggilan atau sapaan berkabung memiliki beberapa fungsi. Berikut ini beberapa fungsi nama panggilan atau sapaan berkabung dalam bahasa Kenyah Lepoq Jalan di Desa Lung Anai, Loa Kulu, Kutai Kartanegara.

(1) Nama panggilan atau sapaan sebagai fungsi identitas dari masyarakat Kenyah Lepoq Jalan

Penggunaan nama panggilan atau sapaan untuk menyapa mitra tutur dalam masyarakat Kenyah Lepoq Jalan dapat menunjukkan identitas sosialnya. Masyarakat Kenyah Lepoq Jalan pun akan bangga dan membutuhkan fungsi identitas ini. Oleh karena itu, pemakaian bentuk nama panggilan atau sapaan berkabung ini masih dilestarikan meskipun mereka sudah jauh dari asalnya. Nama panggilan atau sapaan tersebut menjadi salah satu bagian dari identitas sosial masyarakat Lung Anai karena setiap daerah memiliki kekhasan masing-masing dalam menyapa mitra tuturnya.

(2) Nama panggilan atau sapaan sebagai penanda status mitra tutur

Penggunaan nama panggilan atau sapaan berdasarkan kematian anggota keluarganya dalam masyarakat Kenyah Lepoq Jalan dapat menunjukkan status si mitra tuturnya. Misalnya, Norti dipanggil dengan nama tambahan Balu Norti, berarti status Norti adalah perempuan memiliki suami yang sudah meninggal dunia. Dengan kata lain, Norti mempunyai status sebagai janda karena suaminya meninggal.
(3) Nama panggilan atau sapaan sebagai penanda jenis kelamin

Penggunaan nama panggilan atau sapaan berkaitan dengan kematian anggota keluarga dalam masyarakat Kenyah Lepoq Jalan akan disesuaikan dengan jenis kelamin mitra tuturnya. Karena tidak semua nama panggilan itu dapat digunakan untuk semua jenis kelamin. Misalnya, nama panggilan Ampan hanya digunakan untuk panggilan mitra tutur berjenis kelamin laki-laki, tidak dapat digunakan untuk memanggil mitra tutur berjenis kelamin perempuan. Semua bergantung pada jenis kelamin dan keadaan status mitra tuturnya tersebut.

(4) Nama panggilan atau sapaan sebagai fungsi interaksi sosial

Penggunaan nama panggilan atau sapaan berkabung untuk menyapa mitra tutur dalam masyarakat Kenyah Lepoq Jalan juga merupakan bagian yang penting dalam interaksi masyarakat dengan masyarakat yang lain, khususnya yang satu subetnis Kenyah Lepoq Jalan. Setiap Masyarakat Kenyah Lepoq Jalan di Desa Lung Anai akan menghargai dan menunjukkan rasa empati serta rasa kekeluargaan dalam menggunakan bentuk nama panggilan atau sapaan tersebut. Nama panggilan atau sapaan yang digunakan penutur akan berbeda apabila menghadapi mitra tutur yang berbeda status dan jenis kelaminnya.

(5) Nama panggilan atau sapaan sebagai fungsi kontrol sosial

Nama panggilan atau sapaan berkabung untuk menyapa mitra tutur di Desa Lung Anai selain sebagai keakraban atau kekeluargaan, juga dijadikan alat kontrol sosial karena bentuk nama panggilan atau sapaan tersebut merupakan salah satu penghubung antara masyarakat Kenyah Lepoq Jalan yang satu dengan masyarakat Kenyah Lepoq 
Jalan yang lainnya. Penghubung tersebut berguna untuk saling menghargai, menghormati, dan mengasihi antara yang satu dengan yang lainnya. Dengan demikian, maksud dari fungsi kontrol sosial tersebut, yaitu bentuk nama panggilan atau sapaan tersebut sebagai batas dari sikap-sikap penutur kepada mitra tutur. Batas-batas tersebut yang akan membantu penutur untuk bersikap yang tepat kepada mitra tuturnya. Fungsi kontrol sosial ini lebih menekankan pada batas-batas yang harus diperhatikan si penutur, baik itu batas kesopanan maupun batas emosi dengan mitra tuturnya.

\section{PENUTUP}

Berdasarkan hasil kajian dan pembahasan, dapat disimpulkan hal-hal berikut ini. Bentuk nama panggilan atau sapaan berdasarkan kematian anggota keluarga dalam bahasa Kenyah Lepoq Jalan diklasifikasikan menjadi tiga, yaitu nama panggilan yang bersifat netral (perempuan dan lakilaki), nama panggilan untuk jenis kelamin perempuan, dan nama panggilan untuk jenis kelamin laki-laki. Nama panggilan yang disandingkan di depan nama seseorang, baik laki-laki maupun perempuan (netral) ada sembilan bentuk, yaitu ilun, upu, bayei, encak, sawang, piat tubing, pe'at, ja'at, dan nyawa. Nama panggilan atau sapaan yang ditujukan untuk jenis kelamin perempuan ada sekitar enam bentuk, yaitu utan, tubing, uyung, buyoq, balu, dan abing. Adapun nama panggilan atau sapaan yang ditujukan untuk jenis kelamin laki-laki hanya ada sekitar empat bentuk, yaitu uyau, ampan, belio dan empui.

Terdapat lima fungsi nama panggilan atau sapaan pada bahasa Kenyah Lepoq Jalan di Desa Lung Anai, Kecamatan Loa Kulu, Kutai Kartanegara, yaitu (a) sebagai fungsi identitas dari masyarakat Kenyah Lepoq Jalan, (b) sebagai penanda status mitra tutur, (c) sebagai penanda jenis kelamin, (d) sebagai fungsi interaksi sosial, dan (e) sebagai fungsi kontrol sosial.

\section{DAFTAR PUSTAKA}

Bappeda Kubar. 2012. Penelitian Hukum Adat dan Acara Adat: Lima Subetnis Dayak (Tonyooi, Benuaq, Bahau, Aoheng, dan Kenyah). Kutai Barat: Bappeda dan CV. Citra Kalimantan.

Kridalaksana, Harimurti. 2008. Kamus Linguistik. Jakarta: Gramedia Pustaka Utama.

Liliweri, Alo. 2013. Dasar-Dasar Komunikasi Antarbudaya. Yogyakarta: Pustaka Pelajar.

Martina dan Irmayani. 2004. Sistem Sapaan Bahasa Melayu Ketapang. Jakarta: Departemen Pendidikan Nasional.

Miles, Matthew B. dan A. Michael Huberman. 2007. Analisis Data Kualitatif. (Terjemahan Tjetjep Rohendi Rohidi). Jakarta: UI-Press.

Moleong, J. Lexy. 2005. Metodologi Penelitian Kualitatif. Bandung: Remaja Rosdakarya. Pateda, Mansoer. 1987. Sosiolinguistik. Bandung: Angkasa.

Pusat Bahasa. 2014. Kamus Besar Bahasa Indonesia. Edisi Keempat. Jakarta: PT Gramedia Pustaka Utama.

Rahayu, A. 2000. "Makna Kontekstual Nama Orang pada Masyarakat Dusun Tonggar, Pacarejo, Semanu, Gunungkidul, Daerah Istimewa Yogyakarta". Yogyakarta: UNY (Skripsi).

Saadah, Imarotus, Asrumi, dan Ali Badrudin. 2016. "Penggunaan Kata Sapaan pada Masyarakat Jawa di Desa Jombang Kecamatan Jombang, Kabupaten Jember". Dalam Publika Budaya. Volume 1 (1) September 2016. Hlm. 1-7.

Widoyoko, E. P. 2013. Teknik Penyusunan Instrumen Penelitian. Yogyakarta: Pustaka Pelajar. 